\title{
EFEK DESTINASI PARIWISATA TERHADAP JUMLAH KUNJUNGAN WISATAWAN MANCANEGARA KE ASIA
}

\author{
Agita Arrasy Asthu \\ Kementerian Pariwisata dan Ekonomi Kreatif, Indonesia; agitarrasy@gmail.com
}

\begin{abstract}
Many countries in Asia Pacific make tourism as the main priority for their economic solutions, so the competitiveness of destinations is an important thing to consider. To see the success of tourism destinations, the authors used 13 indicators of tourism destinations competitiveness in The Travel \& Tourism Competitiveness Index (TTCI) as an independent variable, by looking at its effects on the number of foreign tourist visits in the Asia Pacific. This study used multiple linear regression as a method of analysis. The results found that $97.35 \%$ of independent variables simultaneously had an influence on the number of foreign tourists visiting, and individually there were four variables that had a significant effect, namely indicators of (i) Human resources and labour market, (ii) ICT readiness, (iii) Natural resources, and (iv) Ground and port infrastructure. The growth in the number of foreign tourists was directly proportional to the expenditure of foreign tourism.
\end{abstract}

Keywords: foreign exchange, foreign tourist, multiple linear regression, the travel \& tourism competitiveness index, tourism destination

\begin{abstract}
Abstrak
Sehubungan dengan banyak negara di Asia Pasifik menjadikan pariwisata sebagai prioritas pengembangan perekonomian mereka, maka daya saing destinasi menjadi hal penting. Untuk melihat keberhasilan destinasi pariwisata, penulis menggunakan 13 indikator daya saing destinasi pariwisata dalam The Travel \& Tourism Competitiveness Index (TTCI) sebagai variabel independen, dengan melihat pengaruhnya terhadap jumlah kunjungan wisatawan mancanegara (wisman) di Asia Pasifik sebagai variabel dependen. Penelitian ini menggunakan regresi linear berganda sebagai metode analisis. Hasilnya ditemukan bahwa sebesar $97.35 \%$ secara bersamasama variabel independen memberikan pengaruh terhadap jumlah kunjungan wisman, dan secara individual terdapat empat variabel yang berpengaruh signifikan, yaitu (i) indikator SDM dan lapangan pekerjaan, (ii) kesiapan informasi teknologi, (iii) Sumber daya alam, dan (iv) infrastruktur darat dan laut. Pertumbuhan jumlah wisatawan mancanegara berbanding lurus dengan pengeluaran jumlah atau devisa pariwisata.
\end{abstract}

Kata Kunci: destinasi pariwisata, devisa, regresi linear berganda, the travel \& tourism competitiveness index, wisatawan mancanegara 


\section{Pendahuluan}

Pariwisata telah menjadi sektor yang menjanjikan, menggerakkan perekonomian dan memberikan banyak manfaat, tidak hanya industri berskala besar yang mendapatkan keuntungan, bahkan dapat dirasakan 'hingga menetes ke dasar'. Siapapun dapat berpartisipasi untuk mendukung kegiatan pariwisata, hal yang mungkin tidak dimiliki sektor penggerak ekonomi lainnya. Banyak yang menilai pariwisata sebagai mesin pertumbuhan ekonomi dan pembangunan negara, termasuk membantu meningkatkan kesejahteraan ekonomi lokal (Jarvis et al., 2016; Paci \& Marrocu, 2014; Srihadi et al., 2016; Tang \& Tan, 2013). Pariwisata saat ini merupakan salah satu kegiatan ekonomi dengan tingkat pertumbuhan tercepat, pada beberapa negara, pariwisata menjadi sektor yang bertanggung jawab terhadap keberhasilan pertumbuhan ekonomi (Mendola \& Volo, 2017).

Keberhasilan negara dalam mengembangkan daya saing pariwisata menjadi hal yang krusial. Asumsinya, semakin tinggi daya saing pariwisata suatu negara, maka roda perekonomian akan semakin bertumbuh. Hal yang paling mudah dilihat untuk mengukur keberhasilan pariwisata suatu negara yaitu dengan menghitung jumlah kunjungan wisman, yang akan berimplikasi terhadap devisa yang diterima negara tersebut. Jumlah kunjungan wisatawan mancanegara (wisman) sangat berpengaruh terhadap besaran devisa yang diterima oleh negara. Ada hubungan yang nyata antara pengeluaran wisman dengan jumlah hari yang dihabiskan untuk berwisata: semakin lama menghabiskan waktu di destinasi, semakin banyak juga pengeluaran mereka (Marrocu et al., 2015).

Pengembangan destinasi sebagai modal dasar pariwisata menjadi kunci bagaimana negara bisa terus meningkatkan jumlah kunjungan wisman atau inbound. Tiga elemen yang tidak bisa dilepaskan dalam industri pariwisata: (i) wisatawan, (ii) elemen geografis yang terdiri dari wilayah, destinasi, dan (iii) industri. (Mutanga et al., 2017). Masing-masing elemen memiliki penanganan yang berbeda, namun dalam penelitian ini penulis membatasi lingkup objek kajian hanya pada wisman dan destinasi. Tidak ada artinya destinasi yang dikembangkan dengan baik jika tidak bisa mendatangkan wisatawan, kualitas dari destinasi sangat berpengaruh terhadap keputusan wisatawan dalam menentukan tujuan berwisata. Citra destinasi pariwisata memiliki kaitan erat dengan kepercayaan wisatawan (Liu et al., 2019).

Tentu saja destinasi perlu sistem pengelolaan yang baik agar memberikan dampak yang maksimal, dalam hal ini mendatangkan wisman. Wisman memiliki kriteria yang harus dipenuhi dalam menentukan keputusan destinasi yang hendak didatangi, namun pertimbangan yang dimiliki 
oleh setiap wisman berbeda. Destinasi sebaiknya mempelajari indikator yang melatarbelakangi keputusan wisman untuk datang ke suatu tempat, sehingga pengembangan destinasi akan lebih terarah dan memiliki fokus yang jelas. Indikator membantu melacak perubahan dan mengidentifikasi tren, dan dapat digunakan untuk mengukur output dan mengungkapkan kinerja (Mendola \& Volo, 2017). Perspektif ini menguatkan teori bahwa alokasi sumber daya negara untuk menarik lebih banyak wisatawan ke destinasi dengan cara meningkatkan ranking kompetitif (Webster \& Ivanov, 2014).

Destinasi membutuhkan alat ukur dalam mengukur kapasitas yang dimilikinya, jauh lebih baik ketika mengetahui kapasitas yang dimiliki destinasi lain atau bahkan kompetitor. Pengukuran performansi bisa membantu manajemen untuk mengatur proses pekerjaan dan membuat pengambilan keputusan bersama dengan pembaharuan strategi (Sainaghi et al., 2017). Beberapa lembaga berusaha mengukur daya saing destinasi dengan memunculkan nilai dari analisis dan fakta yang menunjukkan pengelola destinasi, nilai dapat dibandingkan dengan kompetitor dan memungkinkan manajerial untuk menentukan tujuan dan mengantisipasi tren pariwisata (Mendola \& Volo, 2017). Kendala muncul ketika indikator menjadi tidak seragam atau terlalu banyak yang dirumuskan untuk membentuk suatu indikator pengukuran, namun pendapat Mendola dan Volo (2017) memberikan penjelasan bahwa sangat tidak mungkin terjadi kesepakatan mengenai indikator pengukuran destinasi, yang dibutuhkan hanya definisi yang universal, diterima secara luas dalam komunitas ilmiah, agar bisa menjadi acuan bersama (Mendola \& Volo, 2017).

Sejak 2008, WEF sudah memformulasikan definisi dan indikator daya saing pariwisata. WEF sendiri adalah organisasi internasional non laba yang didirikan di Jenewa pada 1971. Organisasi yang tidak memiliki unsur keberpihakan atau netral ini menghasilkan beberapa seri laporan penelitian dengan melibatkan anggotanya untuk terus melakukan inisiatif di sektor ekonomi dunia, termasuk pariwisata (The World Economic Forum, n.d.). Sudah tujuh hasil laporan TTCI yang dirilis secara resmi oleh WEF, yakni TTCI tahun 2008, 2009, 2011, 2013, 2015, 2017, dan 2019. Namun untuk membatasi lingkup penelitian, penulis tidak mencantumkan rilis TTCI tahun 2019, karena tidak lengkapnya data pembanding jumlah wisman yang hingga saat tulisan ini dibuat sudah rilis hingga tahun 2018 saja.

Penulis memilih Asia Pasifik sebagai fokus penelitian ini dikarenakan keberhasilan pariwisata dalam menggerakan perekonomian di kawasan tersebut. Menurut laporan yang dibuat oleh United Nation World Travel Organization/UNWTO (2019), pada 2018 wilayah Asia Pasifik 
menduduki peringkat kedua sebagai wilayah yang paling banyak dikunjungi wisman dunia dengan market share sebesar 24,8\% atau 348 juta kunjungan, bahkan laju pertumbuhan wisman dan pendapatan devisa wilayah Asia Pasifik menempati urutan tertinggi di dunia masing-masing menyentuh angka 7\%, jika dibandingkan 2017.

\section{Gambar 1. Jumlah wisman dan devisa pariwisata tahun 2018}

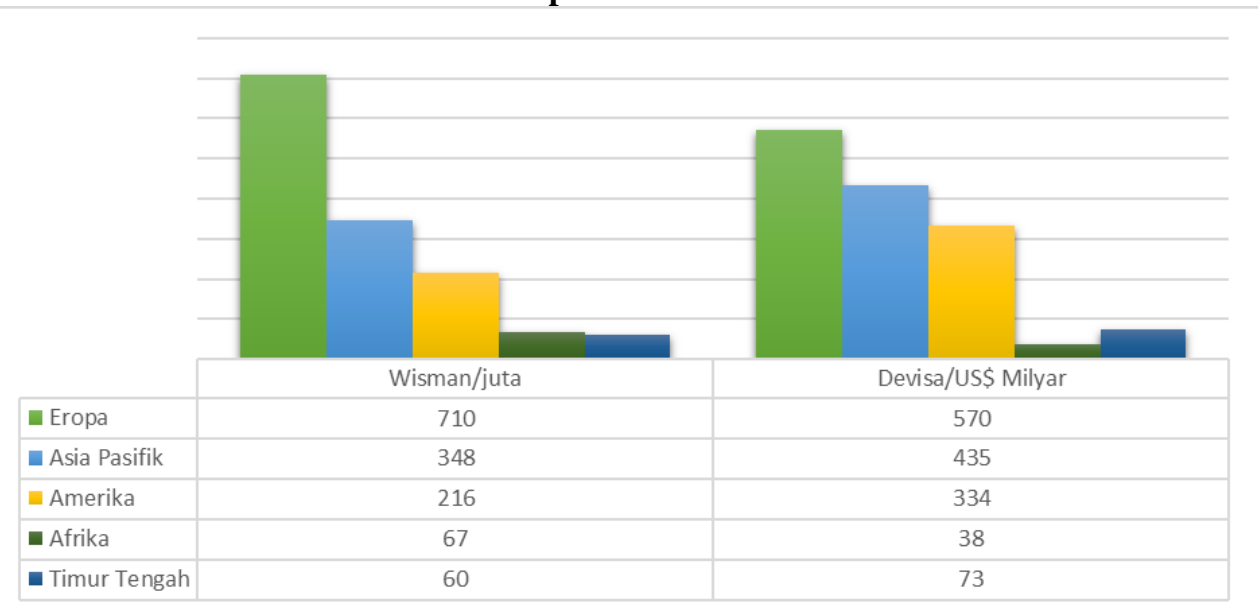

Sumber: (United Nation World Travel Organization, 2019)

Namun, apakah capaian pariwisata Asia Pasifik diimbangi kualitas atau daya saing destinasi pariwisatanya, jika kita melihat tabel di bawah, beberapa negara menunjukkan perkembangan yang baik, meskipun banyak negara yang rankingnya masih di bawah 50 besar.

Tabel 1. Ranking negara Asia Pasifik tahun 2008-2017

\begin{tabular}{llcccccc}
\hline No & Negara & \multicolumn{7}{c}{ Rank TTCI Wilayah Asia Pasifik } \\
\cline { 3 - 8 } & & 2008 & 2009 & 2011 & 2013 & 2015 & 2017 \\
\hline $\mathbf{1}$ & Indonesia & 80 & 81 & 74 & 70 & 50 & 42 \\
\hline $\mathbf{2}$ & Malaysia & 32 & 32 & 35 & 34 & 25 & 26 \\
\hline $\mathbf{3}$ & Thailand & 42 & 39 & 41 & 43 & 35 & 34 \\
\hline $\mathbf{4}$ & Vietnam & 96 & 89 & 80 & 80 & 75 & 67 \\
\hline $\mathbf{5}$ & Singapura & 16 & 10 & 10 & 10 & 11 & 13 \\
\hline $\mathbf{6}$ & Filipina & 81 & 86 & 94 & 82 & 74 & 79 \\
\hline $\mathbf{7}$ & Kamboja & 112 & 108 & 109 & 106 & 105 & 101 \\
\hline $\mathbf{8}$ & Jepang & 23 & 25 & 22 & 14 & 9 & 4 \\
\hline $\mathbf{9}$ & Australia & 4 & 9 & 13 & 11 & 7 & 7 \\
\hline $\mathbf{1 0}$ & Hong Kong & 14 & 12 & 12 & 15 & 13 & 11 \\
\hline $\mathbf{1 1}$ & Tiongkok & 62 & 47 & 39 & 45 & 17 & 15 \\
\hline $\mathbf{1 2}$ & Selandia Baru & 19 & 20 & 19 & 12 & 16 & 16 \\
\hline $\mathbf{1 3}$ & Korea Selatan & 31 & 31 & 32 & 25 & 29 & 19 \\
\hline & & & & & & & \\
\hline
\end{tabular}




\begin{tabular}{llcccccc}
\hline $\mathbf{1 4}$ & Mongolia & 100 & 105 & 101 & 99 & 99 & 102 \\
\hline $\mathbf{1 5}$ & Sri Lanka & 73 & 78 & 81 & 74 & 63 & 64 \\
\hline $\mathbf{1 6}$ & India & 65 & 62 & 68 & 65 & 52 & 40 \\
\hline $\mathbf{1 7}$ & Nepal & 116 & 118 & 112 & 112 & 102 & 103 \\
\hline $\mathbf{1 8}$ & Pakistan & 111 & 113 & 125 & 122 & 125 & 124 \\
\hline $\mathbf{1 9}$ & Bangladesh & 127 & 129 & 129 & 123 & 127 & 125
\end{tabular}

Sumber: (The World Economic Forum, 2008, 2009, 2011, 2013, 2015, 2017)

Indikator data pengukuran daya saing destinasi yang digagas WEF menjadi sangat penting bagi negara sebagai pihak yang paling bertanggung jawab dalam pengelolaan destinasi. Tentu saja, pengelolaan destinasi sama pentingnya dengan kedatangan wisman. Maka dari itu, penelitian ini akan terfokus pada:

1. Besar pengaruh daya saing pariwisata di Kawasan Asia Pasifik yang diukur TTCI (variabel bebas) terhadap jumlah kunjungan wisman (variabel terikat), baik bersama-sama ataupun tunggal.

2. Indikator daya saing pariwisata yang memberikan pengaruh paling dominan terhadap jumlah kunjungan wisman di Asia Pasifik.

\section{Indikator TTCI}

Pariwisata secara teoritis merupakan ilmu interdisipliner, tidak ada disiplin tunggal yang dapat memberikan yang penjelasan yang lengkap, membutuhkan variabel lintas disiplin yang dimiliki organisasi multidisiplin yang kompleks (Sainaghi et al., 2017). Setidaknya TTCI mampu memberikan pengukuran yang dapat diterima kalangan akademisi dan pengelola destinasi. Menurut Mendola dan Volo (2017), indikator yang baik mampu menangkap dan menjelaskan daya saing secara holistik, menurutnya pemilihan atribut harus relevan dan memiliki karakter:
a. Mampu menjelaskan keberagaman destinasi
b. Tidak melihat segmentasi pariwisata, harus melihat secara umum
c. Sesuai dengan indikator pembangunan
d. Mengatasi perbedaan isu dari data
e. Berguna untuk level manajerial 
Penelitian ini menggunakan data TTCI hingga 2017, sehingga variabel yang digunakan merujuk pada tahun TTCI keluaran edisi ke enam tersebut. Terdapat empat indikator TTCI yang terbagi ke dalam 14 subindikator,seperti yang terlampir pada gambar 2 di bawah.

\section{Gambar 2. Pilar TTCI}

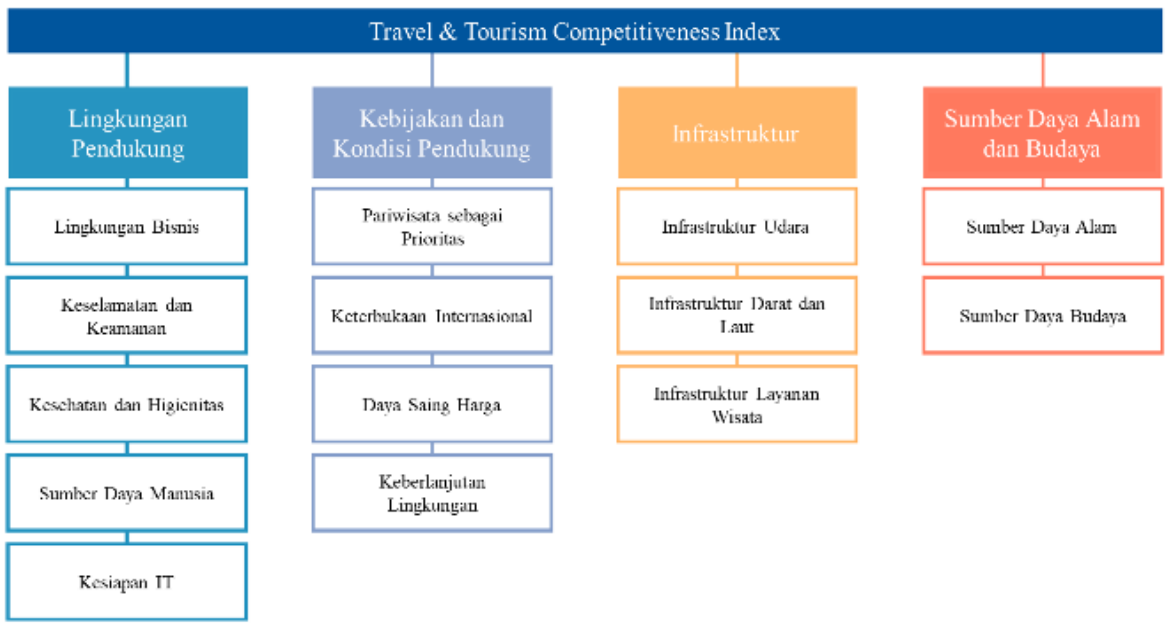

Sumber: (The World Economic Forum, 2017)

\section{Pengaruh Kualitas Destinasi terhadap Wisman dan Ekonomi Negara}

Penulis berasumsi bahwa semakin tinggi daya, maka suatu destinasi akan lebih kompetitif dan menarik lebih banyak wisatawan untuk datang berkunjung, kemudian pengeluaran wisatawan di destinasi akan semakin besar, yang berimplikasi pada peningkatan devisa dan pertumbuhan kesejahteraan ekonomi lokal. Asumsi tersebut sesuai dengan pernyataan Webster dan Ivanov (2014). Bahkan implikasinya jauh lebih besar, terdapat hubungan positif antara kedatangan wisman dengan jumlah pemasukkan negara, stimulasi berbagai macam industri lintas sektor, infrastruktur publik, dan efek pada jumlah SDM (Paci \& Marrocu, 2014). 
Untuk mendongkrak dan memaksimalkan nilai ekonomi, destinasi harus berpikir menggunakan sudut pandang bisnis, dengan mengembangkan produk, pasar, dan pelanggan, untuk menciptakan nilai yang lebih kompetitif. (Kubickova \& Martin, 2020). Hal tersebut tidak lepas dari upaya menguantifikasi nilai kompetitif destinasi dengan berbagai indikator untuk memberikan informasi yang baik kepada pembuat kebijakan dan industri, dan akan membantu mereka mengidentifikasi kekuatan dan kelemahan dalam menarik perhatian kunjungan wisman. (GómezVega \& J Picazo-Tadeo, 2019).

\section{Metode Penelitian}

Penelitian ini menggunakan metode pendekatan kuantitatif, yang menitikberatkan pada pengujian hipotesis sehingga menghasilkan simpulan. Regresi data panel digunakan sebagai alat analisis untuk melihat pengaruh antara variabel dependen dan independen. Berikut adalah tabel independen dan dependen penelitian ini:

Tabel 2. Variabel Penelitian

\begin{tabular}{lcl}
\hline \multicolumn{1}{c}{ Indikator TTCI } & Variabel & \multicolumn{1}{c}{ Keterangan } \\
\hline Inbound (INB) & Y & Wisman \\
\hline Business environment (BE) & X1 & Lingkungan bisnis \\
\hline Savety and security (SC) & X2 & Keselamatan dan keamanan \\
\hline Health and hygiene (HH) & X3 & Kesehatan dan higienitas \\
\hline Human resources and labour market (HRLM) & X4 & Sumber daya manusia \\
\hline ICT readiness (ICTR) & X5 & Kesiapan IT \\
\hline Prioritization of travel \& tourism (PTT) & X6 & Pariwisata sebagai prioritas \\
\hline Price competitiveness (PC) & X7 & Daya saing harga \\
\hline Environmental sustainability (ES) & X8 & Keberlanjutan lingkungan \\
\hline Air transport infrastructure (ATI) & X9 & Infrastrktur udara \\
\hline Ground and port infrastructure (GPI) & X10 & Infrastruktur darat dan laut \\
\hline Tourist service infrastructure (TSI) & X11 & Infrastruktur layanan wisata \\
\hline Natural resources (NR) & X12 & Sumber daya alam \\
\hline Cultural resources and business travel (CRBT) & X13 & Sumber daya budaya \\
\hline Sub dana
\end{tabular}

Sumber: data diolah 
Data diambil dari sumber sekunder berupa data time series dan cross section. Data time series yang dipakai adalah 13 variabel independen TTCI, satu variabel yaitu keterbukaan internasional tidak dipakai karena variabel tersebut baru digunakan pada rilis laporan TTCI tahun 2017. Data jumlah kunjungan wisman ke daerah lokus dengan sumber World Bank sebagai variabel dependen. Data yang digunakan dimulai dari tahun 2008, 2009, 2011, 2013, 2015, dan 2017, dimana itu adalah tahun dirilisnya TTCI. Laporan tahun 2019 tidak digunakan karena banyak data wisman yang belum lengkap, sehingga tidak dapat digunakan. Scope populasi atau lokusnya adalah negara Asia Pasifik dalam TTCI, dengan ketentuan data lengkap dari tahun 2008 hingga 2017, total ada 19 negara di Kawasan Asia Pasifik yang menjadi objek penelitian, yaitu negara Indonesia, Malaysia, Thailand, Vietnam, Singapura, Filipina, Kamboja, Jepang, Australia, Hong Kong, Tiongkok, Selandia Baru, Korea Selatan, Mongolia, Sri Lanka, India, Nepal, Pakistan, dan Bangladesh. Program yang digunakan untuk mengolah data adalah Eviews 9.

\section{Hasil dan Pembahasan}

\section{Hasil}

Menurut Widarjono (2007), tahap pertama yang dilakukan adalah melakukan tiga estimasi model, yakni Common Effect Model (CEM), Fixed Effect Model (FEM), dan Random Effect Model (REM). Persamaan regresi dalam mengestimasi model penelitian adalah:

$$
Y_{\text {it }}=\alpha+\beta_{1} X_{1 \mathrm{it}}+\beta_{2} \mathrm{X}_{2 \mathrm{it}}+\ldots+\beta_{n} \mathrm{X}_{\mathrm{nit}}+\mathrm{e}_{\mathrm{it}}
$$

Yang mana:

$$
\begin{array}{lll}
Y_{\text {it }}=\text { variabel terikat } & \mathrm{t}=\text { periode ke- } \mathrm{t} & \alpha=\text { konstanta } \\
X_{\text {it }}=\text { variabel bebas } & i=\text { entitas ke-i } & \mathrm{e}=\text { variabel diluar model }
\end{array}
$$

Persamaan diperoleh setelah melakukan pengujian terhadap asumsi klasik. Hasil statistik yang diperoleh dalam estimasi CEM, FEM, dan REM adalah sebagai berikut:

Tabel 3. Hasil estimasi CEM, FEM, dan REM

\begin{tabular}{lcccrrr}
\hline \multirow{2}{*}{ Variabel } & \multicolumn{2}{c}{ Common effect } & \multicolumn{2}{c}{ Fixed Effect } & \multicolumn{2}{c}{ Random effect } \\
\cline { 2 - 7 } & t-Statistic & Prob. & t-Statistic & Prob. & t-Statistic & \multicolumn{1}{c}{ Prob. } \\
\hline X1 & 1.381909 & 0.1700 & 0.135653 & 0.8924 & 0.321966 & 0.7482 \\
\hline X2 & -1.397815 & 0.1652 & -1.060146 & 0.2922 & -1.524720 & 0.1305 \\
\hline X3 & -0.372571 & 0.7102 & 1.175296 & 0.2433 & 1.743661 & 0.0843 \\
\hline X4 & 0.233511 & 0.8158 & 4.173146 & 0.0001 & -3.333550 & 0.0012 \\
\hline
\end{tabular}




\begin{tabular}{lrrrrrr}
\hline $\mathbf{X 5}$ & 3.557423 & 0.0006 & 3.362665 & 0.0012 & 3.916183 & 0.0002 \\
\hline $\mathbf{X 6}$ & 2.690840 & 0.0083 & 1.041821 & 0.3006 & 2.332758 & 0.0217 \\
\hline $\mathbf{X} 7$ & 10.325170 & 0.0000 & 0.382083 & 0.7034 & 0.320553 & 0.7492 \\
\hline $\mathbf{X 8}$ & 0.296458 & 0.7675 & 1.420828 & 0.1592 & 1.363034 & 0.1759 \\
\hline $\mathbf{X 9}$ & 0.103266 & 0.9180 & -1.271851 & 0.2070 & 0.467876 & 0.6409 \\
\hline $\mathbf{X 1 0}$ & 0.286739 & 0.7749 & 3.074040 & 0.0029 & -3.306007 & 0.0013 \\
\hline $\mathbf{X 1 1}$ & -1.400523 & 0.1644 & 0.892561 & 0.3747 & 0.374730 & 0.7087 \\
\hline $\mathbf{X 1 2}$ & 3.042284 & 0.0030 & 2.263975 & 0.0262 & 2.146969 & 0.0342 \\
\hline $\mathbf{X 1 3}$ & 4.275988 & 0.0000 & 1.005587 & 0.3176 & 1.052513 & 0.2951 \\
\hline
\end{tabular}

Sumber: data diolah

Tabel di atas menunjukan nilai t statistik dan probabilitas masing-masing model sebagai model terbaik yang terpilih dalam regresi data panel. Hasil estimasi menjelaskan setiap model memiliki nilai signifikansi yang berbeda-beda. Untuk menemukan model yang terbaik di antara ketiganya, maka dilakukan analisis Uji Chow dan Hausman Test (Widarjono, 2007)

Tabel 4. Uji Chow

\begin{tabular}{lrcr}
\hline \multicolumn{1}{c}{ Effects Test } & Statistic & d.f. & Prob. \\
\hline Cross-section F & 51.68783 & $(18,82)$ & 0.000 \\
& 5 & & 0 \\
\hline Cross-section Chi- & 286.5208 & 18 & 0.000 \\
square & 79 & & 0 \\
\hline Sumber: data diolah & & &
\end{tabular}

Sumber: data diolah

Tujuan dari Uji Chow untuk menentukan model yang terbaik antara CEM dan FEM. Berdasarkan tabel di atas maka diperoleh nilai probabilitas Cross-section Chi-square lebih kecil dari alpha $(\alpha)(0.0000<0.05)$, artinya FEM lebih baik digunakan jika dibandingkan dengan CEM.

Tabel 5. Hausman Test

\begin{tabular}{crrl}
\hline Test Summary & Chi-Sq. Statistic & Chi-Sq. d.f. & \multicolumn{1}{l}{ Prob. } \\
\hline Cross-section random & 34.318805 & 13 & 0.0011 \\
\hline
\end{tabular}

Sumber: data diolah

Uji Hausman bertujuan menentukan model yang sesuai antara FEM dan REM. Tabel di atas menunjukan bahwa nilai probabilitas pada Cross-section random lebih kecil dari alpha $(\alpha)$ (0.0011 0.05), artinya FEM lebih baik dari pada REM. Baik Uji Chow ataupun Hausman Test, menilai jika FEM lebih baik dibandingkan dua model lainnya, artinya model regresi data panel yang dipilih adalah FEM.

\section{Uji Asumsi Klasik}


Uji asumsi klasik relevan dilakukan ketika yang terpilih adalah FEM. Pengujian asumsi klasik yang dilakukan adalah uji normalitas, multikolinearitas, heteroskedastisitas, dan autokorelasi.

Tabel 6. Uji normalitas

\begin{tabular}{ll}
\hline Jarque-Bera & $\mathbf{1 . 7 5 3 7 6 0}$ \\
\hline Probability & 0.416079
\end{tabular}

Sumber: data diolah

Pengujian normalitas data menunjukkan nilai Jarque-Bera sebesar 1.753760 dengan nilai Probability 0.416079 lebih besar dari $\alpha(0.05)$. Artinya data sudah terdistribusi dengan normal.

Tabel 7. Uji multikolinearitas

\begin{tabular}{|c|c|c|c|c|c|c|c|c|c|c|c|c|c|}
\hline & X1 & X2 & X3 & X4 & X5 & X6 & $\mathbf{X 7}$ & X8 & X9 & X10 & X11 & X12 & X13 \\
\hline \multirow[t]{3}{*}{ X1 } & 1.00 & 0.76 & 0.77 & 0.72 & 0.81 & 0.50 & - & 0.49 & 0.74 & 0.69 & 0.72 & - & 0.31 \\
\hline & 000 & 9379 & 8721 & 0396 & 3414 & 9021 & 0.41 & 1681 & 9311 & 5065 & 2613 & 0.00 & 1869 \\
\hline & 0 & & & & & & 4593 & & & & & 3218 & \\
\hline \multirow[t]{3}{*}{$\mathbf{X} 2$} & 0.76 & 1.00 & 0.71 & 0.69 & 0.79 & 0.56 & - & 0.43 & 0.68 & 0.58 & 0.63 & 0.09 & 0.35 \\
\hline & 937 & 0000 & 4051 & 1833 & 3820 & 6600 & 0.52 & 8874 & 7514 & 2150 & 9658 & 5509 & 9497 \\
\hline & 9 & & & & & & 1550 & & & & & & \\
\hline \multirow[t]{3}{*}{$\mathbf{X 3}$} & 0.77 & 0.71 & 1.00 & 0.54 & 0.87 & 0.27 & - & 0.28 & 0.63 & 0.58 & 0.73 & - & 0.44 \\
\hline & 872 & 4051 & 0000 & 9479 & 2520 & 0023 & 0.55 & 1548 & 7293 & 7642 & 1533 & 0.00 & 9214 \\
\hline & 1 & & & & & & 8170 & & & & & 9246 & \\
\hline \multirow[t]{3}{*}{ X4 } & 0.72 & 0.69 & 0.54 & 1.00 & 0.66 & 0.58 & - & 0.62 & 0.78 & 0.66 & 0.58 & 0.22 & 0.53 \\
\hline & 039 & 1833 & 9479 & 0000 & 7695 & 2729 & 0.36 & 9543 & 1374 & 9895 & 2168 & 3027 & 6982 \\
\hline & 6 & & & & & & 2858 & & & & & & \\
\hline \multirow[t]{3}{*}{ X5 } & 0.81 & 0.79 & 0.87 & 0.66 & 1.00 & 0.45 & - & 0.40 & 0.77 & 0.68 & 0.80 & 0.02 & 0.54 \\
\hline & 341 & 3820 & 2520 & 7695 & 0000 & 6617 & 0.59 & 3141 & 3435 & 9577 & 8200 & 6565 & 3466 \\
\hline & 4 & & & & & & 6392 & & & & & & \\
\hline \multirow[t]{3}{*}{ X6 } & 0.50 & 0.56 & 0.27 & 0.58 & 0.45 & 1.00 & - & 0.42 & 0.51 & 0.39 & 0.42 & 0.23 & 0.12 \\
\hline & 902 & 6600 & 0023 & 2729 & 6617 & 0000 & 0.09 & 5868 & 0646 & 4712 & 9832 & 7041 & 2388 \\
\hline & 1 & & & & & & 7108 & & & & & & \\
\hline \multirow[t]{4}{*}{$\mathbf{X 7}$} & - & - & - & - & - & - & 1.00 & - & - & - & - & - & - \\
\hline & 0.41 & 0.52 & 0.55 & 0.36 & 0.59 & 0.09 & 0000 & 0.46 & 0.51 & 0.44 & 0.53 & 0.04 & 0.42 \\
\hline & 459 & 1550 & 8170 & 2858 & 6392 & 7108 & & 9504 & 4800 & 4986 & 3840 & 9491 & 7472 \\
\hline & 3 & & & & & & & & & & & & \\
\hline \multirow[t]{3}{*}{ X8 } & 0.49 & 0.43 & 0.28 & 0.62 & 0.40 & 0.42 & - & 1.00 & 0.58 & 0.49 & 0.46 & 0.23 & 0.33 \\
\hline & 168 & 8874 & 1548 & 9543 & 3141 & 5868 & 0.46 & 0000 & 1735 & 8048 & 1588 & 1636 & 8235 \\
\hline & 1 & & & & & & 9504 & & & & & & \\
\hline \multirow[t]{3}{*}{ X9 } & 0.74 & 0.68 & 0.63 & 0.78 & 0.77 & 0.51 & - & 0.58 & 1.00 & 0.66 & 0.82 & 0.42 & 0.67 \\
\hline & 931 & 7514 & 7293 & 1374 & 3435 & 0646 & 0.51 & 1735 & 0000 & 8919 & 8043 & 7556 & 5180 \\
\hline & 1 & & & & & & 4800 & & & & & & \\
\hline \multirow[t]{3}{*}{ X10 } & 0.69 & 0.58 & 0.58 & 0.66 & 0.68 & 0.39 & - & 0.49 & 0.66 & 1.00 & 0.50 & - & 0.52 \\
\hline & 506 & 2150 & 7642 & 9895 & 9577 & 4712 & 0.44 & 8048 & 8919 & 0000 & 6917 & 0.08 & 2568 \\
\hline & 5 & & & & & & 4986 & & & & & 2589 & \\
\hline \multirow[t]{3}{*}{ X11 } & 0.72 & 0.63 & 0.73 & 0.58 & 0.80 & 0.42 & - & 0.46 & 0.82 & 0.50 & 1.00 & 0.28 & 0.48 \\
\hline & 261 & 9658 & 1533 & 2168 & 8200 & 9832 & 0.53 & 1588 & 8043 & 6917 & 0000 & 6850 & 8176 \\
\hline & 3 & & & & & & 3840 & & & & & & \\
\hline \multirow[t]{4}{*}{ X12 } & - & 0.09 & - & 0.22 & 0.02 & 0.23 & - & 0.23 & 0.42 & - & 0.28 & 1.00 & 0.42 \\
\hline & 0.00 & 5509 & 0.00 & 3027 & 6565 & 7041 & 0.04 & 1636 & 7556 & 0.08 & 6850 & 0000 & 7775 \\
\hline & 321 & & 9246 & & & & 9491 & & & 2589 & & & \\
\hline & 8 & & & & & & & & & & & & \\
\hline
\end{tabular}




$\begin{array}{llllllllllllll}\mathbf{X 1 3} & 0.31 & 0.35 & 0.44 & 0.53 & 0.54 & 0.12 & - & 0.33 & 0.67 & 0.52 & 0.48 & 0.42 & 1.00 \\ & 186 & 9497 & 9214 & 6982 & 3466 & 2388 & 0.42 & 8235 & 5180 & 2568 & 8176 & 7775 & 0000 \\ & 9 & & & & & & 7472 & & & & & & \end{array}$

Sumber: data diolah

Hasil pengujian multikolinearitas dikatakan terbebas dari masalah, apabila nilai korelasi antara independen lebih kecil dari 0.90 (90\%). Data di atas menunjukkan bahwa tidak ada yang melebihi 0.90 .

Tabel 8. Uji heteroskedastisitas

\begin{tabular}{llll}
\hline F-statistic & $\mathbf{1 . 4 4 5 6 8 3}$ & Prob. F(13,100) & $\mathbf{0 . 1 5 2 1}$ \\
\hline Obs*R-squared & 18.03546 & Prob. Chi-Square(13) & 0.1562 \\
\hline Scaled explainded SS & 9.719203 & Prob. Chi-Square(13) & 0.7167 \\
\hline
\end{tabular}

Sumber: data diolah

Pengujian heteroskedastisitas dilakukan dengan cara metode white. Diperoleh hasil berupa nilai probabilitas chi squares sebesar 0.1562 , lebih besar dari taraf signifikansi 0.05 , artinya tidak ada heteroskedastisitas.

Tabel 9. Uji autokorelasi

\begin{tabular}{llll}
\hline F-statistic & $\mathbf{0 . 2 6 2 3 1 0}$ & Prob. F(2,97) & $\mathbf{0 . 7 6 9 8}$ \\
\hline Obs*R-squared & 0.607867 & Prob. Chi-Square(2) & 0.7379 \\
\hline
\end{tabular}

Sumber: data diolah

Pengujian terakhir adalah uji autokorelasi. Dapat dikatakan nilai probabilitas chi square sebesar 0.7379 , lebih besar dari taraf signifikansi 0.05 . Artinya data tidak terdapat autokorelasi. Secara keseluruhan tidak ditemukan penyimpangan asumsi klasik pada model atau data.

Tabel 10. Uji Kelayakan Model

\begin{tabular}{lllll}
\hline Variable & Coefficient & $\begin{array}{l}\text { Std. } \\
\text { Error }\end{array}$ & t-Statistic & Prob. \\
\hline $\mathbf{Y}$ & 15.766630 & 1.069275 & 14.745160 & 0.00000 \\
\hline $\mathbf{X 1}$ & 0.015995 & 0.117908 & 0.135653 & 0.89240 \\
\hline $\mathbf{X 2}$ & -0.081362 & 0.076746 & -1.060146 & 0.29220 \\
\hline $\mathbf{X 3}$ & 0.089343 & 0.076017 & 1.175296 & 0.24330 \\
\hline $\mathbf{X 4}$ & 0.471727 & 0.113039 & 4.173146 & 0.00010 \\
\hline $\mathbf{X 5}$ & 0.271517 & 0.080745 & 3.362665 & 0.00120 \\
\hline $\mathbf{X 6}$ & 0.105780 & 0.101533 & 1.041821 & 0.30060 \\
\hline $\mathbf{X 7}$ & 0.031404 & 0.082191 & 0.382083 & 0.70340 \\
\hline $\mathbf{X 8}$ & 0.148739 & 0.104685 & 1.420828 & 0.15920 \\
\hline $\mathbf{X 9}$ & -0.208386 & 0.163845 & -1.271851 & 0.20700 \\
\hline $\mathbf{X 1 0}$ & 0.230567 & 0.075005 & 3.074040 & 0.00290 \\
\hline $\mathbf{X 1 1}$ & 0.065198 & 0.073046 & 0.892561 & 0.37470 \\
\hline
\end{tabular}




\begin{tabular}{|c|c|c|c|}
\hline $\mathbf{X} 12$ & 0.233731 & $0.103239 \quad 2.263975$ & 0.02620 \\
\hline $\mathbf{X 1 3}$ & 0.056323 & $0.056010 \quad 1.005587$ & 0.31760 \\
\hline \multicolumn{4}{|c|}{ Cross-section fixed (dummy variables) } \\
\hline R-squared & 0.980832 & Mean dependent var & 15.384760 \\
\hline $\begin{array}{l}\text { Adjusted R- } \\
\text { squared }\end{array}$ & 0.973586 & S.D. dependent var & 1.463277 \\
\hline $\begin{array}{l}\text { S.E. of } \\
\text { regression }\end{array}$ & 0.237816 & Akaike info criterion & 0.197289 \\
\hline $\begin{array}{l}\text { Sum } \\
\text { squared } \\
\text { resid }\end{array}$ & 4.637645 & Schwarz criterion & 0.965345 \\
\hline $\begin{array}{l}\text { Log } \\
\text { likelihood }\end{array}$ & 20.754540 & Hannan-Quinn criter. & 0.509000 \\
\hline F-statistic & 135.357200 & Durbin-Watson stat & 1.308871 \\
\hline $\begin{array}{l}\text { Prob(F- } \\
\text { statistic) }\end{array}$ & 0.000000 & & \\
\hline
\end{tabular}

Sumber: data diolah

Uji kelayakan model dapat dilihat dari hasil uji f. gambar di atas menunjukan bahwa nilai probabilitas F lebih kecil dari taraf signifikansi $(0.0000<0.05)$, artinya semua variabel independen secara Bersama-sama mempengaruhi variabel dependen. Model layak untuk menginterpretasikan pengaruh variabel independen terhadap variabel dependen. Ditemukan juga nilai adjusted rsquared sebesar 97,35\%, yang menjelaskan proporsi pengaruh semua variabel independen terhadap varibel dependen, sedangkan sebesar 2,65\% dipengaruhi faktor lain di luar model.

Dalam Uji t terdapat dua kategori berdasarkan hasil pengujian hipotesis secara individual. Kategori pertama adalah variabel tunggal yang berpengaruh signifikan terhadap jumlah kunjungan wisman, dan kategori kedua adalah variabel tunggal yang tidak berpengaruh signifikan terhadap jumlah kunjungan wisman. Hal ini didasarkan pada nilai probabilitasnya, jika nilainya lebih kecil dari 0.05, variabel independen tersebut berpengaruh signifikan terhadap varibel dependen, namun jika nilainya lebih besar dari 0.05 maka variabel tersebut tidak perpengaruh signifikan variabel dependen. Berikut pembagiannya berdasarkan gambar di atas:

Tabel 11. Variabel signifikan dan tidak signifikan

\begin{tabular}{ll}
\hline Variabel tunggal berpengaruh signifikan & Variabel tunggal tidak berpengaruh signifikan \\
\hline Human resource and labour market (X4) & Business environment (X1) \\
ICT readiness (X5) & Safety and Security (X2) \\
Ground and Port (X10) & Health and Hygiene (X3) \\
Natural Resources (X12) & Prioritization of T\&T (X6) \\
& Price Competitiveness (X7) \\
\hline
\end{tabular}


Environmental Sustainability (X8)

Air Transport Infrastructure (X9)

Tourist Service Infrastructure (X11)

Cultural Resources \& Business Travel (X13)

Sumber: data diolah

Penelitian ini dilakukan untuk melihat pengaruh varibel independen terhadap variabel dependen. Regresi data panel digunakan untuk melihat hipotesis yang dibuat akan diterima atau ditolak. Tingkat signifikansi yang digunakan sebesar 5\% atau 0.05 . Untuk melihat hasil pengujian hipotesis dari analisis regresi data panel dapat dilihat pada gambar di atas. Berdasarkan tabel di atas dan dengan ketentuan bahwa variabel tunggal yang tidak berpengaruh signifikan dikeluarkan dari model, maka diperoleh persamaan sebagai berikut:

$$
\mathrm{Y}=15.76663+0.471727 * \mathrm{X} 4+0.2715178 * \mathrm{X} 5+0.230567 * \mathrm{X} 10+0.233731 * \mathrm{X} 12
$$

Dari hasil persamaan regresi linear berganda di atas, dapat diinterprestasikan sebagai berikut:

1. Nilai konstanta sebesar 15.766 menunjukkan besarnya nilai konstanta dari Inbound (Y). Dengan asumsi jika variabel Human resource and labour market (X4), ICT readiness (X5), Ground and Port (X10), dan Natural Resources (X12) sama dengan nol atau konstan inbound akan bernilai konstan/tetap sebesar 15.766

2. Koefisien Human resource and labour market (X4) sebesar 0.471, menyatakan bahwa setiap perubahan positif $\mathrm{X} 4$ sebesar 1 satuan, maka $\mathrm{Y}$ akan cenderung mengalami peningkatan sebesar 0.471 satuan. Berarti setiap kenaikan X4 akan cenderung diikuti oleh peningkatan Y dan begitu sebaliknya.

3. Koefisien ICT readiness (X5) sebesar 0.271 , menyatakan bahwa setiap perubahan positif X5 sebesar 1 satuan, maka Inbound (Y) akan cenderung mengalami peningkatan sebesar 0.271 satuan. Berarti setiap kenaikan X5 akan cenderung diikuti oleh peningkatan Y dan begitu sebaliknya.

4. Koefisien Ground and Port (X10) sebesar 0.230, menyatakan bahwa setiap perubahan positif $\mathrm{X} 10$ sebesar 1 satuan, maka Inbound (Y) akan cenderung mengalami peningkatan sebesar 0.230 satuan. Berarti setiap kenaikan X10 akan cenderung diikuti oleh peningkatan Y dan begitu sebaliknya.

5. Koefisien Natural Resources (X12) sebesar 0.233, menyatakan bahwa setiap perubahan positif $\mathrm{X} 12$ sebesar 1 satuan, maka (Y) akan cenderung mengalami peningkatan sebesar 0.233 satuan. Berarti setiap kenaikan X12 akan cenderung diikuti oleh peningkatan Y dan begitu sebaliknya. 


\section{Pembahasan}

Secara bersama-sama, 13 variabel dalam TTCI berpengaruh sebesar 97,35\% terhadap jumlah kunjungan wisman di Asia Pasifik. Sisanya sebesar 2,65\% dipengaruhi oleh variabel lain di luar amatan penelitian. Penelitian ini membuktikan bahwa indikator yang dicantumkan oleh TTCI dalam model penghitungan daya saing tergolong baik, terutama pada konteks melihat pengaruh kualitas destinasi terhadap jumlah kunjungan wisman di Asia Pasifik. Hasil penelitian membuktikan, ternyata hipotesis penulis di awal yang menyebutkan bahwa kualitas destinasi berpengaruh terhadap jumlah kunjungan wisman terbukti benar, semakin baik dan tinggi nilai pada TTCI, semakin bertumbuh jumlah kunjungan wisman ke destinasi, yang akan berimplikasi pada devisa negara.

Hanya ada empat varibel yang berpengaruh signifikan secara individual terhadap variabel kunjungan wisman, jika diurutkan besaran pengaruhnya maka akan seperti di bawah ini:

1. X4/HRLM (SDM dan lapangan pekerjaan)

2. X5/ICTR (kesiapan informasi teknologi)

3. X10/NR (sumber daya alam)

4. X12/GP (infrastruktur darat dan laut)

Keempat variabel memiliki pengaruh yang paling besar terhadap jumlah kunjungan wisman di Asia Pasifik, temuan ini bisa menjadi pertimbangan pihak pengelola destinasi dalam hal ini negara untuk lebih fokus pada pengembangan dan pembangunan empat variabel destinasi pariwisata tersebut.

Satu, SDM dan lapangan pekerjaan memiliki pengaruh paling besar dengan peran yang strategis, selain meningkatkan jumlah wisman, juga berimplikasi langsung pada masyarakat dengan pemanfaatan serapan tenaga kerja di bidang hospitality. Hospitality yang baik adalah kunci dari SDM pariwisata, kunci keberhasilan perusahaan yang bergerak di bidang hospitality dengan memanfaatkan praktik SDM berkinerja tinggi, yang di dalamnya terdiri atas (i) sistem penjadwalan yang baik, (ii) pelatihan dan pengembangan keterampilan, (iii) sistem perekrutan yang baik dan transparan, (iv) kebijakan manajemen kinerja, dan lain-lain yang mengarah pada profitabilitas serta kepuasan SDM (Hinkin \& Tracey, 2010). Untuk membentuk SDM yang handal, peran pendidikan sangat fundamental, baik formal maupun informal, namun sebaiknya standarisasi tetap menjadi 
prioritas, guna mentransformasi angkatan kerja yang profesional dan handal. Pengembangan sekolah pariwisata jenjang menengah dan tinggi, pelaksanaan kursus, dan pelatihan di bidang hospitality, adalah salah satu contoh yang bisa dilakukan negara dalam memberikan fasilitas peningkatan kualitas dan kuantitas angkatan kerja pada sektor pariwisata.

Dua, kesiapan teknologi informasi menjadi varibel kedua yang paling berpengaruh terhadap destinasi di Asia Pasifik. Industri 4.0 merubah perilaku dan kebiasaan Pariwisata dewasa kini (Buhalis \& Law, 2008; Navío-Marco et al., 2018), terbukti dari bagaimana teknologi IT menggantikan banyak peran teknologi konvensional dan merubah wajah pariwisata. Digitalisasi tidak bisa dihindari, maka pariwisata yang harus beradaptasi. Hulu ke hilir pariwisata tidak pernah lepas dari ketergantungan teknologi informasi, (i) dari mulai wisatawan mencari informasi seputar destinasi, (ii) menentukan pemesanan transportasi, akomodasi, dan, atraksi baik menuju ataupun dari destinasi, (iii) saat di destinasi, dengan menggunakan aplikasi peta, transportasi online, dan media sosial, (iv) bahkan setelah kembali dari destinasi, seseorang menggunakan media sosial untuk berbagi pengalaman saat berwisata. Perilaku wisatawan tersebut memaksa pariwisata untuk menyesuaikan diri. Teknologi informasi memainkan peran penting dalam meningkatkan daya saing destinasi pariwisata (Berne et al., 2012; Buhalis \& O'Connor, 2005). Sharing economy (contoh Air BnB) yang sempat mengemparkan bahkan hingga saat ini di beberapa negara belum bisa diatasi, termasuk di Indonesia, menunjukan bahwa teknologi informasi menunjukan perubahan yang cepat dan sering kali tidak terduga. Destinasi harus bijak dalam menyikapi dan mengadaptasi teknologi informasi agar wisatawan ataupun industri tidak terkena efek negatif.

Ketiga, Sumber daya alam. Temuan penelitian membuktikan bahwa kegiatan dengan pemanfaatan alam sebagai daya tarik masih menjadi magnet utama yang memengaruhi jumlah kunjungan wisman di Asia Pasifik, baik itu sightseeing, leisure, ataupun melibatkan aktivitas fisik. Warisan alam yang diakui, jumlah keberagaman spesies flora dan fauna, area alam yang dilindungi, wisata alam yang dikemas baik, adalah beberapa poin yang dinilai pada variabel sumber daya alam. Sumber daya alam setiap destinasi memiliki keunikannya sendiri, tidak bisa menjadi sama atau disamakan satu dengan lainnya. Tugas manusia untuk merawat dan melestarikan alam yang dikehendaki menjadi destinasi wisata. Pengelolaan destinasi dengan konsep keberlanjutan menjadi kunci dari pengembangan sumber daya alam. Faktanya, dengan bertambahnya jumlah pengunjung atau wisatawan akan merefleksikan kondisi objek wisata 
berbasis alam, peran manajerial dalam mengelola daya lenting lingkungan menjadi kunci keberhasilan keberlanjutan sumber daya alam (Kim et al., 2019).

Keempat, infrastruktur darat dan laut. Pada Sebagian besar negara di Asia Pasifik, jalur darat dan laut masih mendominasi penggunaan tipe transportasi yang pakai wisman. Bahkan di beberapa negara penggunaan transportasi darat dan laut jika dijumlahkan menyentuh angka lebih dari 50\%, lebih banyak dibandingkan penggunaan transportasi udara. Ini dibuktkan oleh data kunjungan wisman yang diperoleh dari United Nation World Tourism Organization (UNWTO) pada 2018, seperti yang terlampir pada gambar 3 di bawah:

\section{Gambar 3. Jumlah wisman menggunakan transportasi darat dan laut 2018}

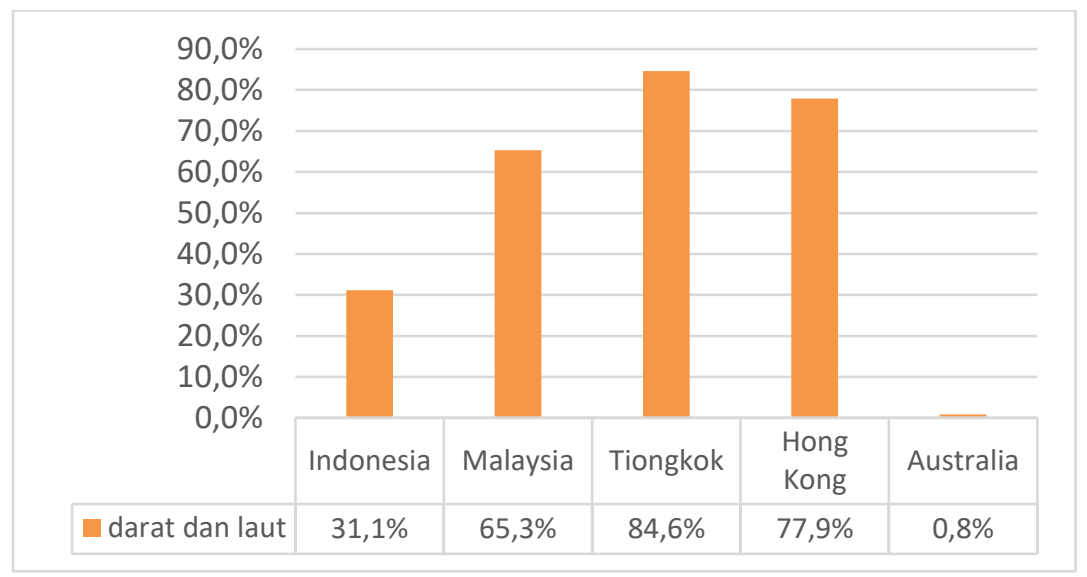

Sumber: United Nation World Tourism Organization, 2020

Bahkan di Indonesia, sebagai negara kepulauan, angka kunjungan wisman melalui darat dan laut, menyentuh angka 31.1\%. Hal ini disebabkan oleh ramainya lalu lintas cross border melalui Kalimantan, Nusa Tenggara Timur, dan Kepulauan Riau, tempat mayoritas kendaraan darat dan laut banyak digunakan. Adapun jumlah kunjungan wisman melalui udara tinggi, disebabkan jarak yang jauh atau negara destinasi tidak bisa dilalui melalui darat ataupun laut. Namun, transportasi darat tingkat pemakaian ataupun frekuensinya sangat tinggi ketika wisman sudah berada di destinasi, dengan asumsi wisman memakai kendaraan darat ataupun laut sebagai pilihan utama. Infrastruktur dan transportasi darat menyediakan kemudahan akses ke dan dari destinasi dan meningkatkan kegiatan ekonomi di wilayah yang dilalui. Masyarakat lokal sangat terbantu dengan dijadikannya jalan sebagai jalur menuju destinasi, kegiatan ekonomi akan mudah ditemui sepanjang jalur ke destinasi (Kanwal et al., 2020). 
Keempat varibel menjadi penting ketika negara di Asia Pasifik menjadikan pariwisata sebagai penggerak utama perekonomian mereka. Temuan keempat varibel ini bisa dijadikan alternatif dalam model pengembangan pariwisata dalam menarik wisman di Asia Pasifik. Implikasi dari kedatangan wisman sesuai dengan dugaan awal penulis yang menyebutkan bahwa jumlah wisman berpengaruh terhadap devisa. Data pariwisata Kawasan Asia Pasifik yang menunjukkan bahwa devisa yang hasilkan dari pengeluaran wisman bertumbuh sebesar $150 \%$ dalam waktu kurang dari 10 tahun (2008-2017), berbanding lurus dengan kunjungan wisman, data dapat dilihat pada Gambar 4 di bawah.

Gambar 4. Jumlah kunjungan dan pengeluaran wisman di Asia Pasifik tahun 2008 - 2017

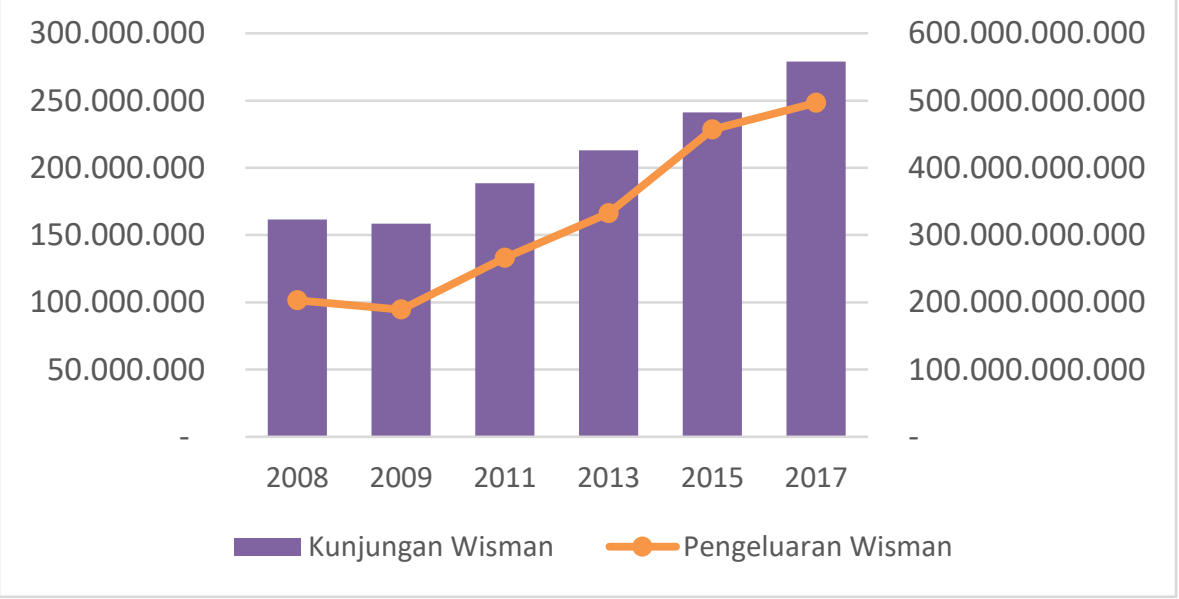

Sumber: World Bank, 2020b, 2020a)

Tabel di atas mendukung pernyataan Tolkach dan kawan-kawan (2016), bahwa masa depan pariwisata di wilayah Asia Pasifik secara umum sangat baik, terutama dari sisi kunjungan wisatawan dan perolehan devisa. Bahkan beberapa negara sangat mengandalkan pariwisata sebagai ujung tombak pertumbuhan perekonomiannya, tidak terkecuali Indonesia, sejak tahun 2015 hingga 2020 pariwisata selalu masuk program pengembangan prioritas nasional, diandalkan karena menunjukan performansi yang baik, bahkan di tahun 2018 pariwisata menjadi sumber penghasil devisa terbesar kedua setelah kelapa sawit. Industri pariwisata di sebagian besar negara Asia Pasifik pada umumnya berkembang pesat selama sepuluh tahun terakhir (Assaf, 2012). Adapun negara lain di Kawasan Asia Pasifik seperti Thailand, Vietnam, dan Selandia Baru yang menjadikan pariwisata sebagai sumber penggerak perekonomian selain Indonesia. Sejalan dengan pendapat Assaf (2012), yang mengatakan bahwa pariwisata dipandang sebagai sektor pendorong dan sumber utama pendapatan devisa bagi banyak negara di wilayah Asia dan Pasifik. 


\section{Simpulan}

Semua varibel independen pada penelitian ini mempengaruhi variabel dependen secara bersamasama sejumlah 97,35\%. Tentu saja akan berimplikasi pada jumlah devisa yang diperoleh, hingga implikasinya terhadap kegiatan ekonomi. Keempat varibel yang mempengaruhi variabel dependen secara terpisah bisa dijadikan fokus dan prioritas pengembangan destinasi pariwisata di Asia Pasifik. Keempat variabel itu adalah (i) HRLM atau SDM dan lapangan pekerjaan, (ii) ICTR atau kesiapan informasi teknologi, (iii) NR atau sumber daya alam, dan (iv) GP atau infrastruktur darat dan laut. Kesenjangan antara kebutuhan destinasi dan yang wisatawan inginkan, dipengaruhi oleh beberapa hal, seperti: perubahan demografis, sosial-ekonomi dan psikologis dari suatu daerah. Jika pariwisata tidak berhasil bersaing dengan industri lain, yang disebabkan oleh kurangnya pemahaman perencanaan pariwisata yang matang, pertumbuhan positif bisa saja terhenti dan mengakibatkan rusaknya pembangunan jangka panjang (Tolkach et al., 2016). Jika melihat fakta yang disajikan seperti jumlah kunjungan dan pertumbuhan wisman, jumlah dan pertumbuhan devisa yang dihasilkan, saat ini pariwisata adalah daya tarik utama di Asia Pasifik. Perlu diingat bersama-sama, bahwa pariwisata merupakan salah satu sektor yang sangat rentan pengaruh eksternal.

Penelitian ini tidak bisa digeneralisirkan jika ingin melihat pengaruh varibel independen terhadap dependen pada regional selain Asia Pasifik. Untuk penelitian lanjutan disarankan melengkapi TTCI dan jumlah wisman tahun 2019. Fokus penelitian bisa diubah sesuai kebutuhan fokus regional atau pemilihan beberapa variabel yang bisa menjelaskan maksud dari penelitian.

\section{Referensi}

Assaf, A. G. (2012). Benchmarking The Asia Pacific Tourism Industry : A Bayesian Combination Of DEA And Stochastic Frontier. Tourism Management, 33(5), 1122-1127. https://doi.org/10.1016/j.tourman.2011.11.021

Berne, C., Garcia-Gonzalez Margarita, M., \& Mugica, J. (2012). How ICT Shifts The Power Balance Of Tourism Distribution Channels. Tourism Management, 33(1), 205-214. https://doi.org/10.1016/j.tourman.2011.02.004

Buhalis, D., \& Law, R. (2008). Progress In Information Technology And Tourism Management: 20 Years On And 10 Years After The Internet-The State Of Etourism Research. Tourism Management, 29(4), 609-623. https://doi.org/10.1016/j.tourman.2008.01.005

Buhalis, D., \& O’Connor, P. (2005). Information Communication Technology Revolutionizing Tourism. Tourism Recreation Research, 30(3), 7-16. 
https://doi.org/10.1080/02508281.2005.11081482

Gómez-Vega, M., \& J Picazo-Tadeo, A. (2019). Ranking World Tourist Destinations With A Composite Indicator Of Competitiveness: To Weigh Or Not To Weigh? Tourism Management, 72(January 2018), 281-291. https://doi.org/10.1016/j.tourman.2018.11.006

Hinkin, T. R., \& Tracey, J. B. (2010). What Makes It So Great?: An Analysis Of Human Resources Practices Among Fortune's Best Companies To Work For. Cornell Hospitality Quarterly, 51(2), 158-170. https://doi.org/10.1177/1938965510362487

Jarvis, D., Stoeckl, N., \& Liu, H. B. (2016). The Impact Of Economic, Social And Environmental Factors On Trip Satisfaction And The Likelihood Of Visitors Returning. Tourism Management, 52, 1-18. https://doi.org/10.1016/j.tourman.2015.06.003

Kanwal, S., Rasheed, M. I., Pitafi, A. H., Pitafi, A., \& Ren, M. (2020). Road And Transport Infrastructure Development And Community Support For Tourism: The Tole Of Perceived Benefits, And Community Satisfaction. Tourism Management, 77(June 2019), 104014. https://doi.org/10.1016/j.tourman.2019.104014

Kim, Y., Kim, C., Kun, D., Lee, H., Ii, R., \& Andrada, T. (2019). Quantifying Nature-Based Tourism In Protected Areas In Developing Countries By Using Social Big Data. Tourism Management, 72(December 2018), 249-256. https://doi.org/10.1016/j.tourman.2018.12.005

Kubickova, M., \& Martin, D. (2020). Exploring The Relationship Between Government And Destination Competitiveness: The TALC Model Perspective. Tourism Management, 78(December 2019), 104040. https://doi.org/10.1016/j.tourman.2019.104040

Liu, J., Wang, C., Fang, S., \& Zhang, T. (2019). Scale Development For Tourist Trust Toward A Tourism Destination. Tourism Management Perspectives, 31(July), 383-397. https://doi.org/10.1016/j.tmp.2019.07.001

Marrocu, E., Paci, R., \& Zara, A. (2015). Micro-economic Determinants Of Tourist Expenditure: A Quantile Regression Approach. Tourism Management, 50, 13-30. https://doi.org/10.1016/j.tourman.2015.01.006

Mendola, D., \& Volo, S. (2017). Building Composite Indicators In Tourism Studies: Measurements And Applications In Tourism Destination Competitiveness. Tourism Management, 59, 541-553. https://doi.org/10.1016/j.tourman.2016.08.011

Mutanga, C. N., Vengesayi, S., Chikuta, O., Muboko, N., \& Gandiwa, E. (2017). Travel Motivation And Tourist Satisfaction With Wildlife Tourism Experiences In Gonarezhou And Matusadona National Parks, Zimbabwe. Journal of Outdoor Recreation and Tourism, 20(June), 1-18. https://doi.org/10.1016/j.jort.2017.08.001

Navío-Marco, J., Ruiz-Gómez, L. M., \& Sevilla-Sevilla, C. (2018). Progress In Information Technology And Tourism Management: 30 Years On And 20 Years After The Internet Revisiting Buhalis \& Law's Landmark Study About Etourism. Tourism Management, 69(May 2018), 460-470. https://doi.org/10.1016/j.tourman.2018.06.002

Paci, R., \& Marrocu, E. (2014). Tourism And Regional Growth In Europe. Papers in Regional Science, 93(S1), S25-S50. https://doi.org/10.1111/pirs.12085

Sainaghi, R., Phillips, P., \& Zavarrone, E. (2017). Performance Measurement In Tourism Firms: A Content Analytical Meta-approach. Tourism Management, 59, 36-56. https://doi.org/10.1016/j.tourman.2016.07.002

Srihadi, T. F., Hartoyo, Sukandar, D., \& Soehadi, A. W. (2016). Segmentation Of The Tourism Market For Jakarta: Classification Of Foreign Visitors' Lifestyle Typologies. Tourism Management Perspectives, 19, 32-39. https://doi.org/10.1016/j.tmp.2016.03.005

Tang, C. F., \& Tan, E. C. (2013). How Stable Is The Tourism-led Growth Hypothesis In Malaysia? 
Evidence From Disaggregated Tourism Markets. Tourism Management, 37, 52-57. https://doi.org/10.1016/j.tourman.2012.12.014

The World Economic Forum. (n.d.). Our Mission | World Economic Forum. Retrieved April 11, 2020, from https://www.weforum.org/about/world-economic-forum

The World Economic Forum. (2008). The Travel \& Tourism Competitiveness Report 2008. The World Economic Forum. (2009). The Travel \& Tourism Competitiveness Report 2009. The World Economic Forum. (2011). The Travel \& Tourism Competitiveness Report 2011. The World Economic Forum. (2013). The Travel \& Tourism Competitiveness Report 2013. The World Economic Forum. (2015). The Travel \& Tourism Competitiveness Report 2015. The World Economic Forum. (2017). The Travel \& Tourism Competitiveness Report 2017.

Tolkach, D., Chon, K. K. S., \& Xiao, H. (2016). Asia Pacific Tourism Trends : Is The Future Ours To See ? Asia Pacific Tourism Trends : Is The Future Ours To See ? Asia Pacific Journal of Tourism Research, 1665(April), 1-19. https://doi.org/10.1080/10941665.2015.1118395

United Nation World Tourism Organization. (2020). All Countries: Inbound Tourism: Arrivals By Mode Of Transport 1995 - 2018 (01.2020): Tourism Statistics: Vol , No 1. https://www.eunwto.org/doi/suppl/10.5555/unwtotfb0000271519952018202001

United Nation World Travel Organization. (2019). International Tourism Highlights 2019 Edition. https://doi.org/https://www.e-unwto.org/doi/pdf/10.18111/9789284421152?download=true

Webster, C., \& Ivanov, S. (2014). Transforming Competitiveness Into Economic Benefits: Does Tourism Stimulate Economic Growth In More Competitive Destinations? Tourism Management, 40, 137-140. https://doi.org/10.1016/j.tourman.2013.06.003

Widarjono, A. (2007). Ekonometrika: Teori Dan Aplikasi Untuk Ekonomi Dan Bisnis. Ekonisia.

World Bank. (2020a). International Tourism, Expenditures (Current US\$) | Data. https://data.worldbank.org/indicator/ST.INT.XPND.CD

World Bank. (2020b). International Tourism, Number Of Arrivals | Data. https://data.worldbank.org/indicator/st.int.arvl 